\title{
STUDIES ON THE PASSIVATION OF ALUMINIUM IN CHROMATE AND MOLYBDATE SOLUTIONS
}

\author{
C. B. Breslin, G. Treacy* and W. M. Carroll $\dagger$ \\ *Department of Chemistry, St. Patricks College, Maynooth, Co. Kildare, Ireland \\ †Department of Chemistry, University College, Galway, Ireland
}

\begin{abstract}
Results on the electrochemical behaviour of aluminium in aggressive chloride solutions containing molybdate and dichromate anions are presented and discussed. An ennoblement in the pitting potential of aluminium was observed in dichromate-containing solutions and in non-acidic molybdatecontaining solutions. It was proposed that reduction of the molybdate and dichromate species occurred at flawed regions in the passive film, but that the larger polymeric molybdate species, formed in acid solutions, could not be accommodated at the flawed regions. An oxidation peak, observed at -1200 to $-1400 \mathrm{mV}(\mathrm{SCE})$, in the molybdate-containing solution was attributed to the growth of a mixed aluminium-molybdenum passive layer. The complete passivation of an aluminium electrode, undergoing meta-stable pitting, was achieved by the introduction of dichromate anions into the test solution. This was attributed to a transformation process whereby chloride-containing aluminium hydroxy complexes were converted into hydrated aluminium oxides.
\end{abstract}

\section{INTRODUCTION}

THE passivation of aluminium, by chromium and molybdenum, in aqueous halide solutions has been studied in some detail. ${ }^{1-10}$ These elements, when alloyed with aluminium, or present as salts of chromates and molybdates in solution, improve the corrosion resistance of aluminium and many aluminium alloys. However, the mechanism by which passivity is imparted to aluminium by these species is not well understood and a number of different mechanistic proposals have been advanced over the years in this regard.

Several investigators have concentrated on identifying the nature of the passive films formed under these passivating conditions. Augustynski ${ }^{1}$ found that films formed on aluminium immersed in chromate solutions were composed of $\mathrm{Cr}$ (III) and $\mathrm{Al}(\mathrm{III})$ oxides, together with a significant degree of adsorbed $\mathrm{Cr}(\mathrm{VI})$ species. A similar conclusion was reached by Abd Rabbo et al. ${ }^{2}$ from SIMS data. A rapid uptake of chromium from solution was attributed to the reduction of $\mathrm{CrO}_{4}^{2-} / \mathrm{Cr}_{2} \mathrm{O}_{7}^{2-}$ at flaws in the surface film, while a more gradual uptake was associated with penetration of $\mathrm{CrO}_{4}^{2-} / \mathrm{Cr}_{2} \mathrm{O}_{7}^{2-}$ anions at the outer layer of the film. The formation of a $\mathrm{CrOOH}$ barrier layer, on polarizing a sputter-deposited $\mathrm{Al}-\mathrm{Cr}$ alloy in $0.1 \mathrm{M} \mathrm{KCl}$ solution, was proposed by Moshier et al. ${ }^{3,4}$ It was assumed that such a layer would inhibit oxidation of the aluminium substrate and restrict the chloride anions from reaching the metal-film interface. These authors explained the interaction of molybdates with aluminium in a similar fashion, associating the ennoblement of the pitting potential 
with a molybdate-rich region at the film surface that inhibited the ingress of chloride anions to the metallic interface. Shaw et al..$^{5}$ identified a number of molybdate species within or on the passive film formed on aluminium polarized in a molybdate solution. They showed, also, that the chemistry of the passive film varied as a function of the molybdate concentration in solution.

McCafferty and co-workers ${ }^{7-9}$ have explained the ennoblement of the pitting potentials observed for $\mathrm{Al}-\mathrm{Cr}$ and $\mathrm{Al}$-Mo alloys, in halide solutions, in terms of the $\mathrm{pH}$ of zero charge model for pit initiation. The $\mathrm{pH}$ of zero charge of the hydrated oxide of molybdenum and chromium is 2.0 and 6.25 , respectively, compared to the value of 9.1 for the hydrated oxide of pure aluminium. According to this analysis chloride adsorption will occur only at $\mathrm{pH}$ values acidic to the $\mathrm{pH}$ of zero charge; thus on alloying aluminium with chromium and molybdenum, adsorption of the halide anion is inhibited and the pitting potential is shifted in the electropositive direction. Szklarska-Smialowska ${ }^{11}$ proposes yet another viewpoint indicating that the development of pits, and areas of localized attack, is controlled by the solubility of the oxidized alloying elements in acid solutions. She obtained a very good correlation between the solubility of the oxidized species in acid solutions and the pitting potentials of Al-Cr alloys, but similar data for the molybdenum system were not as encouraging.

In most of the previous reports, elaborate techniques have been used in an effort to identify the nature of the modified surface films formed in these solutions, but little information on the electrochemical behaviour of the samples is available, other than data relating to the extent of displacement of the pitting potential in relatively low concentrations of neutral chloride electrolytes. In this communication, the electrochemical behaviour of pure aluminium, in aggressive solutions to which are added quantities of molybdates and chromates, is investigated in an attempt to provide additional information on the role of chromium and molybdenum in passivating aluminium. In contrast to earlier works, more aggressive test solutions, containing high halide concentrations are used.

\section{EXPERIMENTAL METHOD}

Aluminium of $99.99 \%$ purity was used in wire form, with a diameter of $0.5 \mathrm{~mm}$, for all test samples. These wire samples were ground manually with a polishing cloth and washed with water and methanol. The aluminium wire was bent to form a working electrode in a manner similar to that used by Stockert and Boehni, ${ }^{12}$ the bend ensuring that the measurements are not influenced by the texture of the wire or by the effects of sharp edges. The upper portion of the bent electrode was covered in a beeswax-colophony resin, this was necessary in experiments where the volume of the test solution was changed during testing and it maintained, also, a constant electrode surface area $\left(1.1 \mathrm{~cm}^{2}\right)$ for immersion in each experiment. Test solutions were prepared from AnalaR grade reagents and distilled water. Chromium was introduced into the test solution as $\mathrm{Na}_{2} \mathrm{Cr}_{2} \mathrm{O}_{7}$, and molybdenum as $\mathrm{Na}_{2} \mathrm{MoO}_{4}$.

Electrochemical measurements were made using an EG\&G Versastat controlled by the model 342 corrosion measurement software package. The electrochemical cell consisted of a Pyrex glass cell, graphite auxiliary electrodes and a saturated calomel reference electrode. In potentiodynamic tests a scan rate of $1 \mathrm{mV} \mathrm{s}^{-1}$ was employed and the potential was scanned from $-2.0 \mathrm{~V}(\mathrm{SCE})$ (unless otherwise stated) up to the breakdown potential. In potentiostatic measurements, the test samples were initially polarized at $-2.0 \mathrm{~V}$ in the halide solution for a $2 \mathrm{~min}$ period, to ensure a reproducible surface, ${ }^{13,14}$ and then the required potential was applied and the current monitored as a continuous function of time on an $x-t$ recorder. Studies which involved the assessment of the passivity-inducing effects of molybdates or chromates during polarization of the test specimen, in halide solutions, were initiated by adding appropriate amounts of dissolved $\mathrm{Na}_{2} \mathrm{Cr}_{2} \mathrm{O}_{7}$ or $\mathrm{Na}_{2} \mathrm{MoO}_{4}$ salts to the cell $\mathrm{NaCl}$ solution which was 
agitated, then, with nitrogen to ensure rapid mixing of the added salts. All potentials reported are with respect to the saturated calomel electrode.

Studies on the uptake of the passivating species on aluminium were carried out using aluminium powder, $99.99 \%$; mean particle size, 45 microns. The aluminium powder was allowed to stand in the various test solutions for $1 \mathrm{~h}$, the solution was then filtered off and the changes in the molybdate and chromate concentrations were calculated. A Pye Unicam absorption spectrometer, with an air-acetylene flame, was used to measure molybdate concentrations, changes in the chromate concentrations were measured with a Milton Ray ultra violet spectrometer.

\section{EXPERIMENTAL RESULTS}

The polarization behaviour of pure aluminium in molybdate- and chromatecontaining solutions, with $0.5 \mathrm{~mol} \mathrm{dm}{ }^{-3} \mathrm{NaCl}$ as the aggressive electrolyte, was studied using potentiodynamic techniques. Some representative potentiodynamic polarization plots are shown in Fig. 1. In Fig. $1 \mathrm{~A}$, the polarization plots obtained in a $0.5 \mathrm{~mol} \mathrm{dm}^{-3} \mathrm{NaCl}$ solution containing $0.1 \mathrm{~mol} \mathrm{dm}^{-3} \mathrm{Na}_{2} \mathrm{MoO}_{4}$ at $\mathrm{pH}$ values of 7.0 , 5.0 and 2.0 , and the plot obtained in a neutral $0.5 \mathrm{~mol} \mathrm{dm}^{-3} \mathrm{NaCl}$ solution with a 0.05 mol dm ${ }^{-3} \mathrm{Na}_{2} \mathrm{MoO}_{4}$ addition are shown. These plots are the average of several measurements as a poor degree of reproducibility was obtained using this procedure; in fact variations, in the pitting potential, as high as $100 \mathrm{mV}$ (SCE) could be obtained from run to run under certain conditions. More consistent pitting potential data could be obtained on allowing the electrode to stand in the molybdate solution for a $10 \mathrm{~h}$ period before polarizing in the molybdate-containing chloride solution, or on polarizing, in the cathodic region, for longer periods of time. The reproducibility was sufficient to draw conclusions on the effects of molybdate additions on the electrochemical activity of the electrode. A much higher degree of passivity was achieved, reflected by the electropositive shift in the pitting potential, in non-acidic solutions. The aluminium electrode polarized in the neutral molybdate-containing chloride solution remained passive until potentials in the region of $-360 \mathrm{mV}(\mathrm{SCE})$ were reached. Only the corrosion potential was shifted in the electropositive direction, in the acidic solutions, giving rise to a considerable reduction in the passive region. As expected, the most significant shift in the pitting potential was evident with the 0.1 mol dm ${ }^{-3} \mathrm{Na}_{2} \mathrm{MoO}_{4}$ addition, with molybdate concentrations lower than $0.0025 \mathrm{~mol}$ $\mathrm{dm}^{-3}$ having no effect on the magnitude of the breakdown potentials.

A noteworthy feature evident from the polarization plots depicted in Fig. 1A is the anodic maximum observed in the region of $-1300 \mathrm{mV}$ (SCE). This activity was observed, also, on polarizing the aluminium electrode in chloride solutions, to which molybdate additions were made, at potentials in the region of -1200 to -1400 $\mathrm{mV}(\mathrm{SCE})$. In Fig. 1B a representative plot is shown. After a $20 \mathrm{~min}$ period, in which the electrode was polarized at $-1350 \mathrm{mV}(\mathrm{SCE})$ in a $0.5 \mathrm{~mol} \mathrm{dm} \mathrm{dm}^{-3} \mathrm{NaCl}$ solution, sufficient molybdate was added to the working solution to provide a $0.1 \mathrm{~mol} \mathrm{dm}^{-3}$ molybdate solution, but the chloride concentration was maintained constant. The current increased, immediately, in a very rapid manner, and then, subsequently decayed.

The effects of $0.04,0.05,0.1$ and $0.2 \mathrm{~mol} \mathrm{dm}^{-3} \mathrm{Na}_{2} \mathrm{Cr}_{2} \mathrm{O}_{7}$ additions, made to a 0.5 mol dm $\mathrm{d}^{-3} \mathrm{NaCl}$ electrolyte, on the polarization behaviour of aluminium are shown in Fig. 1C. In this case a much higher degree of reproducibility was achieved, consistent pitting potential data within $20 \mathrm{mV}$ (SCE) from test to test were obtained. As evident from the plots the pitting potentials are shifted to more noble values with increasing 
(a)

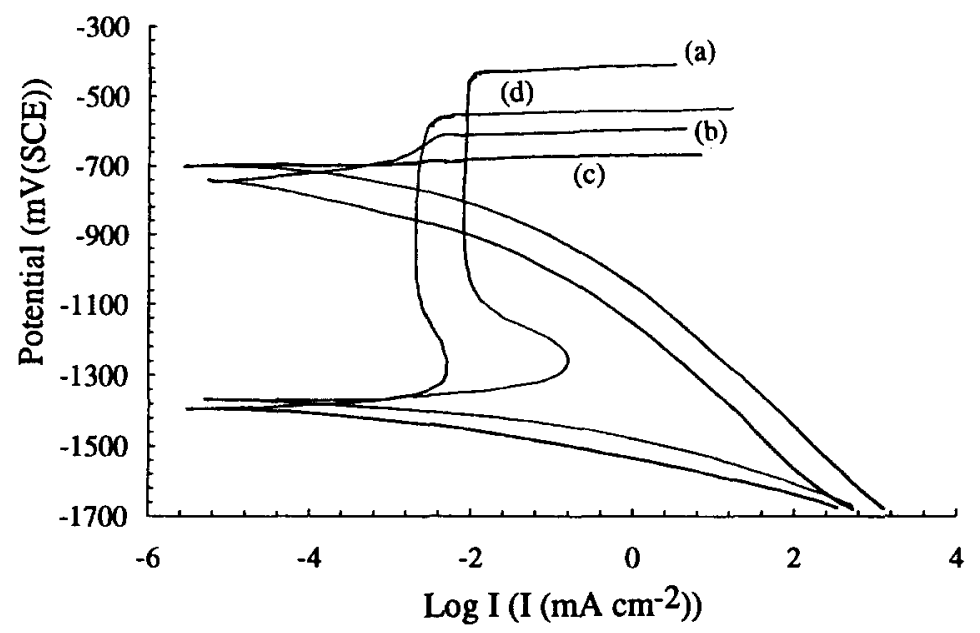

(b)

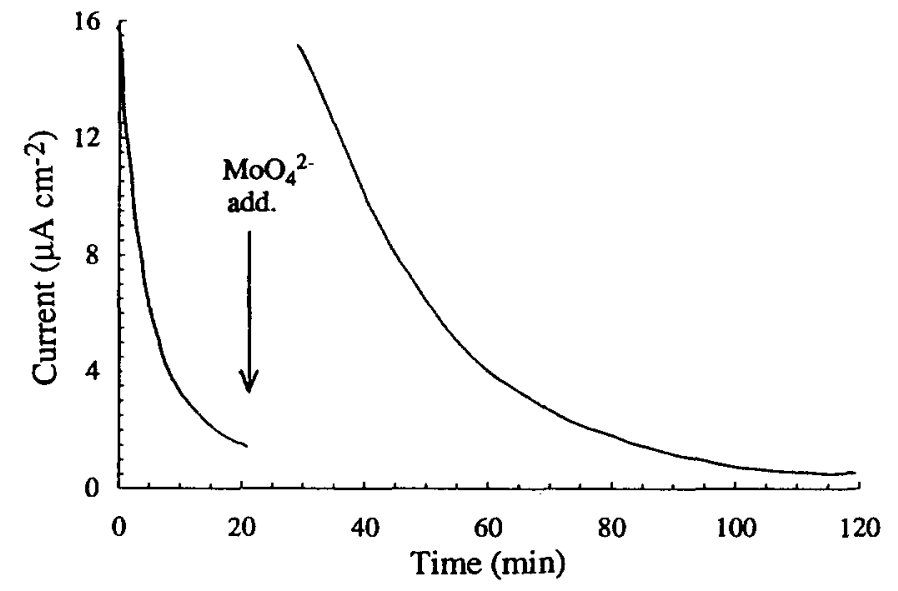

(c)

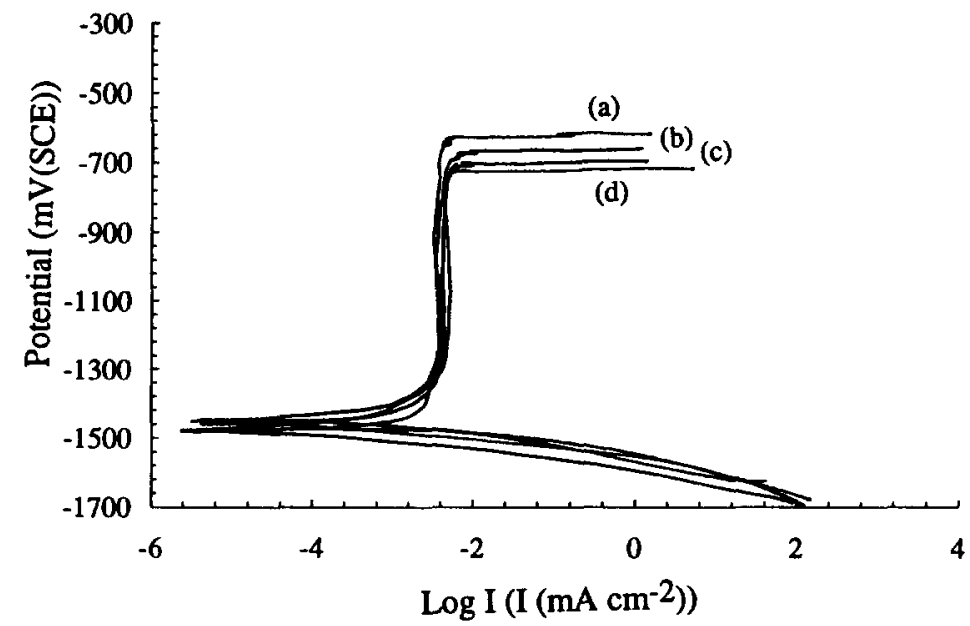


dichromate concentrations. The extent of displacement of the pitting potentials in these solutions was not as significant as that observed with comparable concentrations of the molybdate species. The $\mathrm{pH}$ of the test solution had little effect on the pitting potentials.

In Fig. 2, plots, showing the pitting potential of aluminium as a function of the chloride and dichromate concentrations, are presented. It is evident, again, from these plots that increasing dichromate concentrations inhibit the onset of pitting attack, but more importantly, that the degree of inhibition depends on the concentration of the aggressive chloride anion. With the same concentrations of dichromate, $0.2 \mathrm{~mol} \mathrm{dm}^{-3} \mathrm{Na}_{2} \mathrm{Cr}_{2} \mathrm{O}_{7}$, the pitting potential measured in a $0.05 \mathrm{~mol} \mathrm{dm}^{-3}$ $\mathrm{NaCl}$ solution is shifted from -640 to $-460 \mathrm{mV}(\mathrm{SCE})$ but in a $2.0 \mathrm{~mol} \mathrm{dm}^{-3} \mathrm{NaCl}$ solution it is shifted only from -760 to $-710 \mathrm{mV}(\mathrm{SCE})$. Similar trends were observed in molybdate-containing chloride solutions with pitting potentials as high as $+1000 \mathrm{mV}$ (SCE) being measured in $0.01 \mathrm{~mol} \mathrm{dm}^{-3} \mathrm{NaCl}$ solutions containing 0.1 mol dm ${ }^{-3} \mathrm{Na}_{2} \mathrm{MoO}_{4}$.

These trends, observed in Fig. 2, appeared to be connected with the extent of interaction of the passivating agent with the electrode surface. In Fig. 3, the degree of uptake of dichromate, expressed in units of mmoles per $100 \mathrm{~g}$ of aluminium powder, is shown as a function of the concentrations of the dichromate in aggressive solutions of varying concentrations of chloride. It is clear from these plots that the uptake of chromium on aluminium is associated with the concentration of the aggressive anions in the test solution. The smaller uptake of chromium in the more concentrated chloride solutions could well be connected with the fact that little displacement in the pitting potential is observed on polarizing aluminium in these solutions, as shown in Fig. 2. Similar plots were obtained with molybdate additions.

The influence of molybdate and dichromate additions on the electrochemical behaviour of aluminium during meta-stable activation repassivation was determined using extended current-time measurements. The aluminium electrode was polarized for a $25 \mathrm{~min}$ period at $-755 \mathrm{mV}(\mathrm{SCE})$ in a $0.5 \mathrm{~mol} \mathrm{dm}^{-3} \mathrm{NaCl}$ solution. These conditions were sufficient to promote the onset of meta-stable activationrepassivation. Sufficient dichromate, or molybdate was then added to the test solutions to provide $0.05 \mathrm{~mol} \mathrm{dm}^{-3} \mathrm{Na}_{2} \mathrm{Cr}_{2} \mathrm{O}_{7}$ or $0.1 \mathrm{~mol} \mathrm{dm}{ }^{-3} \mathrm{Na}_{2} \mathrm{MoO}_{4}$ concentrations in a $0.5 \mathrm{~mol} \mathrm{dm}^{-3} \mathrm{NaCl}$ solution. The potentials applied to the electrodes were still maintained at $-755 \mathrm{mV}$ (SCE). Typical profiles are shown in Fig. $4 \mathrm{~A}$ and $\mathrm{B}$, respectively. The point of addition of the passivating agent is marked by the vertical arrows in these plots. Noticeably different behaviours were observed with molybdate and dichromate additions. On addition of the $\mathrm{Na}_{2} \mathrm{Cr}_{2} \mathrm{O}_{7}$ solution the current fluctuations ceased immediately and the passive current continued to decay in a

Fig. 1. (A) Potentiodynamic polarization plots of $99.99 \% \mathrm{Al}$ in (a) $0.5 \mathrm{~mol} \mathrm{dm}^{-3} \mathrm{NaCl}, 0.1 \mathrm{~mol} \mathrm{dm}^{-3}$ $\mathrm{Na}_{2} \mathrm{MoO}_{4}, \mathrm{pH}=7.0$; (b) $0.5 \mathrm{~mol} \mathrm{dm}{ }^{-3} \mathrm{NaCl}, 0.1 \mathrm{~mol} \mathrm{dm}^{-3} \mathrm{Na}_{2} \mathrm{MoO}_{4}, \mathrm{pH}=5.0$; (c) $0.5 \mathrm{~mol} \mathrm{dm}^{-3} \mathrm{NaCl}$, $0.1 \mathrm{~mol} \mathrm{dm}^{-3} \mathrm{Na}_{2} \mathrm{MoO}_{4}, \mathrm{pH}=2.0$; (d) $0.5 \mathrm{~mol} \mathrm{dm}^{-3} \mathrm{NaCl}, 0.05 \mathrm{~mol} \mathrm{dm}^{-3} \mathrm{Na}_{2} \mathrm{MoO}_{4}, \mathrm{pH}=7.0$. (B) Potentiostatic current-time plot of $99.99 \%$ Al polarized at $-1350 \mathrm{mV}(\mathrm{SCE})$ in a neutral $0.5 \mathrm{~mol} \mathrm{dm}^{-3}$ $\mathrm{NaCl}$ solution, to which was added a $0.1 \mathrm{~mol} \mathrm{dm}{ }^{-3} \mathrm{Na}_{2} \mathrm{MoO}_{4}$ solution after 20 min passivation period. (C) Potentiodynamic polarization plots of $99.99 \% \mathrm{Al}$ in neutral $0.5 \mathrm{~mol} \mathrm{dm}^{-3} \mathrm{NaCl}$ solutions containing (a) $0.2 \mathrm{~mol} \mathrm{dm}^{-3} \mathrm{Na}_{2} \mathrm{Cr}_{2} \mathrm{O}_{7}$; (b) $0.1 \mathrm{~mol} \mathrm{dm}^{-3} \mathrm{Na}_{2} \mathrm{Cr}_{2} \mathrm{O}_{7}$; (c) $0.05 \mathrm{~mol} \mathrm{dm}^{-3} \mathrm{Na}_{2} \mathrm{Cr}_{2} \mathrm{O}_{7}$; (d) $0.04 \mathrm{~mol} \mathrm{dm}^{-3}$ $\mathrm{Na}_{2} \mathrm{Cr}_{2} \mathrm{O}_{7}$. 


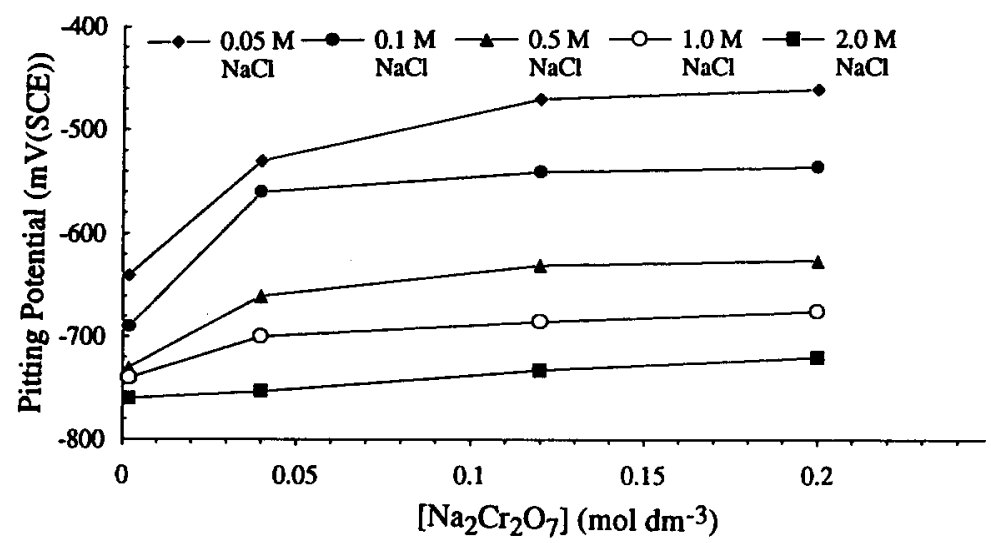

Fig. 2. Pitting potentials, $\mathrm{mV}(\mathrm{SCE})$, of $99.99 \% \mathrm{Al}$ as a function of the concentration of $\mathrm{Na}_{2} \mathrm{Cr}_{2} \mathrm{O}_{7}, \mathrm{~mol} \mathrm{dm}{ }^{-3}$, in neutral $\mathrm{NaCl}$ solutions; concentrations of $\mathrm{NaCl}$ solutions (mol $\mathrm{dm}^{-3}$ ) shown in plot.

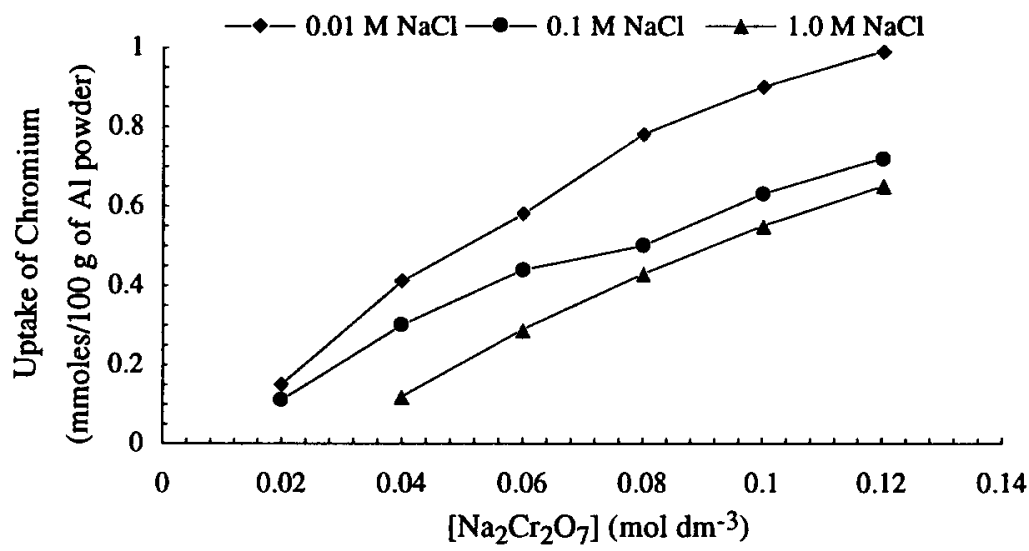

FIG. 3. Uptake of chromium on aluminium powder, mmoles of chromium per $100 \mathrm{~g}$ of powder, as a function of the concentrations of $\mathrm{NaCl}$ and $\mathrm{Na}_{2} \mathrm{Cr}_{2} \mathrm{O}_{7}\left(\mathrm{~mol} \mathrm{dm}^{-3}\right)$; concentrations of $\mathrm{NaCl}$ are shown in the plot.

smooth manner. This seemed to suggest an immediate inhibition to the initiation of meta-stable pitting attack. However, this inhibitory effect depended on the dichromate concentration; with only partial elimination of the current fluctuations being observed with the much lower dichromate concentrations. In contrast, no immediate response was noted on the addition of the molybdate solution. The frequency and magnitude of the current fluctuations, decreased, only slightly, on extended passivation and complete passive conditions, similar to those observed with the dichromate, were never achieved, regardless of the concentration of molybdate or chloride used. The introduction of molybdate under these experimental conditions was deemed to have little effect in promoting the onset of passivation of the meta-stable pits as a similar gradual reduction in the frequency and magnitude of the current fluctuations, 


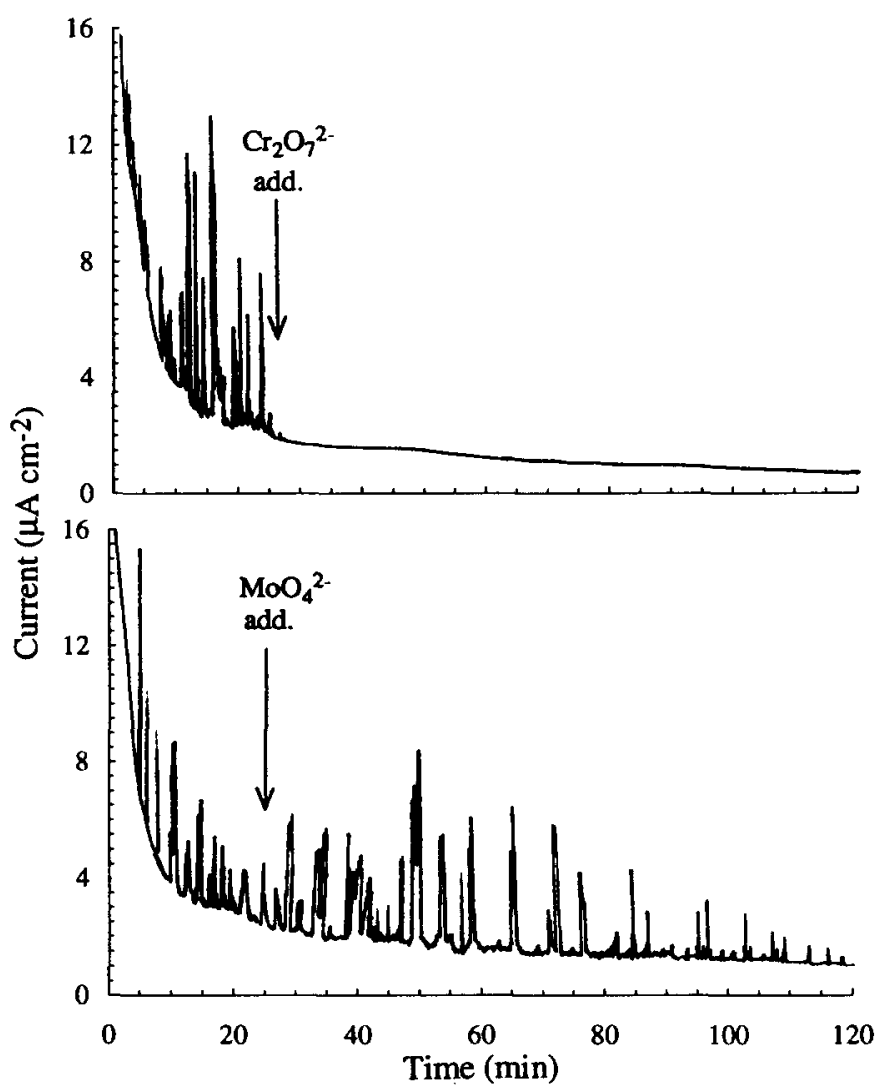

FIG. 4. (A) Potentiostatic current-time plot of $99.99 \%$ Al, polarized at $-755 \mathrm{mV}$ (SCE), in a neutral $0.5 \mathrm{~mol} \mathrm{dm}{ }^{-3} \mathrm{NaCl}$ solution, to which was added a $0.05 \mathrm{~mol} \mathrm{dm}^{-3} \mathrm{Na}_{2} \mathrm{Cr}_{2} \mathrm{O}_{7}$ solution after a 25 min passivation period. (B) Potentiostatic current-time plot of $99.99 \%$ $\mathrm{Al}$, polarized at $-755 \mathrm{mV}(\mathrm{SCE})$, in a neutral $0.5 \mathrm{~mol} \mathrm{dm}^{-3} \mathrm{NaCl}$ solution, to which was added a $0.1 \mathrm{~mol} \mathrm{dm}^{-3} \mathrm{Na}_{2} \mathrm{MoO}_{4}$ solution after a $25 \mathrm{~min}$ passivation period.

on prolonged polarization of aluminium in chloride solutions, was observed in a previous study. ${ }^{15}$

In Fig. 5A and $\mathrm{B}$, data measuring the extent to which passivity can be maintained in the presence of molybdate and chromate species are presented. For these plots the aluminium electrodes were polarized, from $-1800 \mathrm{mV}$ at a scan rate of $1 \mathrm{mV} \mathrm{s}^{-1}$, in a $0.5 \mathrm{~mol} \mathrm{dm}^{-3} \mathrm{NaCl}$ solution containing the passivating addition, up to a required potential, at which point the specimen was held and the current monitored. This potential was chosen so as to provide conditions where the sample was passive in the presence of the passivating species, but would pit under normal conditions. The plot in Fig. $5 \mathrm{~A}$ was obtained with a $0.1 \mathrm{~mol} \mathrm{dm}{ }^{-3}$ molybdate addition to $0.5 \mathrm{~mol} \mathrm{dm}^{-3}$ chloride solution. After a certain induction period, an irreversible increase in the current is noted, indicating the onset of attack. This induction period depended on the applied potential; more electropositive potentials reduced the induction period. For example, at $-500 \mathrm{mV}(\mathrm{SCE})$ the induction period was measured at $8 \mathrm{~min}$, while at $-700 \mathrm{mV}(\mathrm{SCE})$ it increased to $24 \mathrm{~min}$. The surface continued to remain passive 


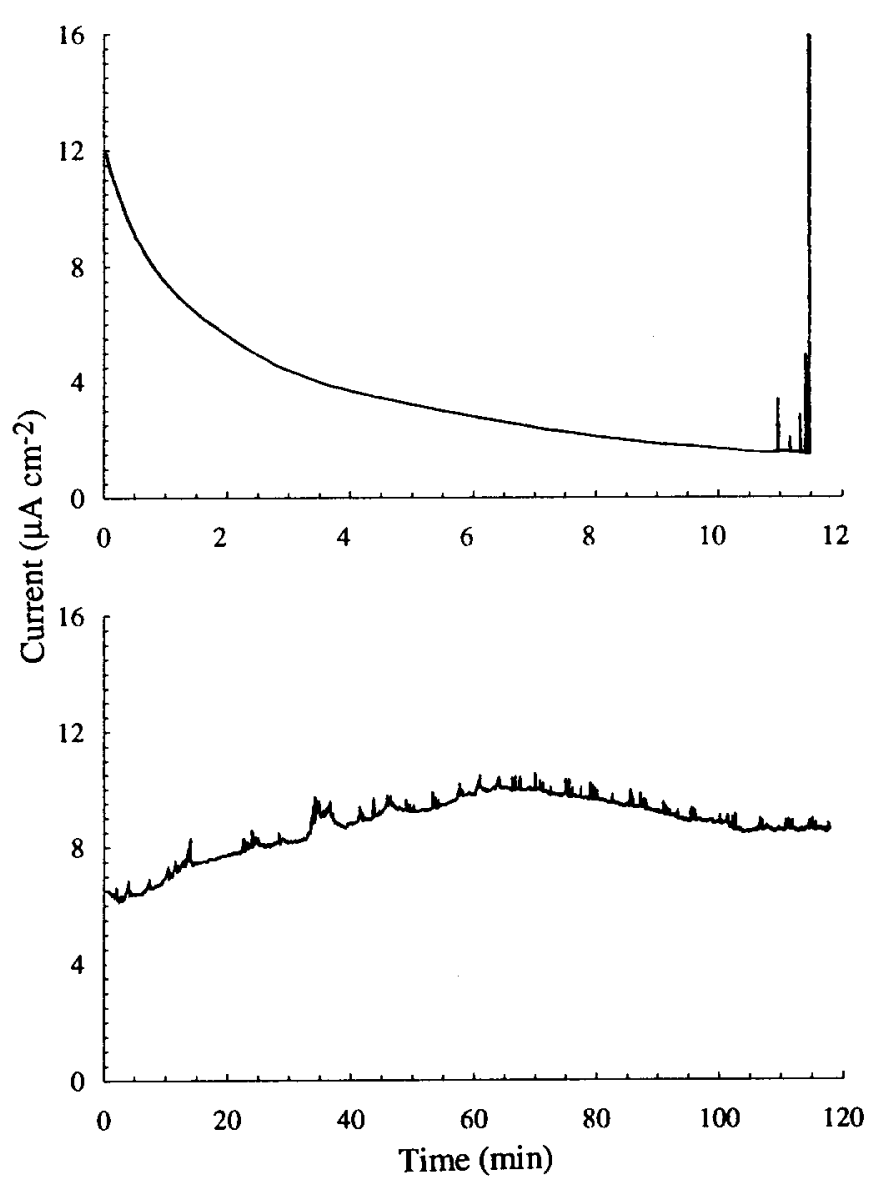

Fig. 5. (A) Potentiostatic current-time plot of $99.99 \%$ Al, polarized at $-610 \mathrm{mV}(\mathrm{SCE})$, in a $0.5 \mathrm{~mol} \mathrm{dm}{ }^{-3} \mathrm{NaCl}$ solution containing $0.1 \mathrm{~mol} \mathrm{dm}^{-3} \mathrm{Na}_{2} \mathrm{MoO}_{4}$ following potentiodynamic polarization, in the same solution, from $-1800 \mathrm{mV}$ (SCE) up to $-610 \mathrm{mV}$ (SCE). (B) Potentiostatic current-time plot of $99.99 \% \mathrm{Al}$, polarized at $-680 \mathrm{mV}(\mathrm{SCE})$, in a $0.5 \mathrm{~mol}$ $\mathrm{dm}^{-3} \mathrm{NaCl}$ solution containing $0.05 \mathrm{~mol} \mathrm{dm}{ }^{-3} \mathrm{Na}_{2} \mathrm{Cr}_{2} \mathrm{O}_{7}$ following potentiodynamic polarization, in the same solution, from $-1800 \mathrm{mV}(\mathrm{SCE})$ up to $-680 \mathrm{mV}$ (SCE).

with dichromate additions, as shown in the plot depicted in Fig. $5 \mathrm{~B}$ for a $0.5 \mathrm{~mol}$ $\mathrm{dm}^{-3} \mathrm{NaCl}$ and $0.05 \mathrm{~mol} \mathrm{dm}{ }^{-3} \mathrm{Na}_{2} \mathrm{Cr}_{2} \mathrm{O}_{7}$ solution with the electrode polarized to $-680 \mathrm{mV}(\mathrm{SCE})$. The current slightly increased up to an equilibrium value, but the current fluctuations varied little with time and at no stage did complete activation occur.

\section{DISCUSSION}

In this communication, studies on the passivating abilities of molybdate and chromate anions, in test solutions which are more aggressive than previously used by many investigators, are discussed. Also, longer testing periods are considered, achieved by monitoring the current-time transients of aluminium specimens, under varying test conditions, over several hundred minutes. This facilitated a true 
evaluation of the passivity-promoting ability of these species under highly aggressive test conditions.

The relationships between the pitting potential of aluminium, the chloride concentration, molybdate or chromate concentrations (Figs 1 and 2), and the degrees of chromate uptake on the aluminium surface (Fig. 3), indicate clearly that the degree of passivation depends on the extent of uptake of the passivating agent. This is further connected to the concentration of chloride in solution, with the higher chloride concentrations obviating the uptake of the passivating species dissolved in solution. Although the concept of competitive adsorption between the passivating and aggressive anions at the metal-solution interface, advanced by several investigators, ${ }^{16-18}$ may appear as an attractive possibility in this analysis it is difficult to visualise the formation of a complete adsorption layer of $\mathrm{MoO}_{4}^{2-}$ anions on the electrode surface, or indeed the manner in which a monolayer of $\mathrm{Cr}_{2} \mathrm{O}_{7}^{2-}$ of $\mathrm{CrO}_{4}^{-}$ species could be accommodated on the oxide-covered surface.

An alternative possible explanation involves an oxidation-reduction process whereby reduction of the passivating anion occurs at flawed areas on the hydrated oxide-covered surface. A precursor step to this reaction may well be the adsorption of the passivating species, ${ }^{19,20}$ but only at the flawed regions, competing with the adsorption of the chloride anions at the same points. The driving force for the dissolution of aluminium at these regions (essentially oxide free) combined with the oxidizing nature of the dichromate anion and the partial oxidizing nature of the molybdate anion should favour oxidation-reduction reactions of the following form: ${ }^{21}$

$$
\begin{array}{ll}
2 \mathrm{Al}+\mathrm{Cr}_{2} \mathrm{O}_{7}^{2-}+8 \mathrm{H}^{+}=\mathrm{Al}_{2} \mathrm{O}_{3} 3 \mathrm{H}_{2} \mathrm{O}+2 \mathrm{Cr}^{3+}+\mathrm{H}_{2} \mathrm{O} & E=2.38 \mathrm{~V} \\
\mathrm{MoO}_{4}^{2-}+2 \mathrm{H}^{+}+2 \mathrm{H}_{2} \mathrm{O}+2 \mathrm{Al}=\mathrm{Mo}+\mathrm{Al}_{2} \mathrm{O}_{3} 3 \mathrm{H}_{2} \mathrm{O} & E=1.56 \mathrm{~V} \\
\mathrm{MoO}_{4}^{2-}+5 \mathrm{H}^{+}+\mathrm{Al}=\mathrm{Mo}^{3+}+(1 / 2) \mathrm{Al}_{2} \mathrm{O}_{3} 3 \mathrm{H}_{2} \mathrm{O}+\mathrm{H}_{2} \mathrm{O} & E=1.46 \mathrm{~V} \\
3 \mathrm{MoO}_{4}^{2-}+6 \mathrm{H}^{+}+2 \mathrm{Al}=3 \mathrm{MoO}_{2}+\mathrm{Al}_{2} \mathrm{O}_{3} 3 \mathrm{H}_{2} \mathrm{O} & E=1.71 \mathrm{~V}
\end{array}
$$

where the $E$ values are calculated for neutral conditions, with $\mathrm{Cr}^{3+}$ and $\mathrm{Mo}^{3+}$ concentrations set equal to $1 \times 10^{-6} \mathrm{~mol} \mathrm{dm}^{-3}$. Here, $\mathrm{Mo}, \mathrm{Mo}^{3+}$ and $\mathrm{MoO}_{2}$ species are formed and $\mathrm{Cr}$ (VI) is reduced to $\mathrm{Cr}$ (III). The subsequent formation of molybdenum oxides with differing oxidation states may account for the detection of several states of molybdenum within the passive film. ${ }^{3-5}$ Likewise, the reduction of the $\mathrm{Cr}$ (VI) to $\mathrm{Cr}$ (III) at the flawed regions accounts for the detection of $\mathrm{Cr}$ (III) oxides, 2,22,23 for the conclusions, that dichromate does not prevent the local breakdown of the film, but stimulates the repair of the active region, ${ }^{24}$ and for the fact that $\mathrm{Cr}$ (III) species are found on aluminium supporting air-formed films but $\mathrm{Cr}$ (VI) species are detected only on aluminium supporting anodized films..$^{6,25-27} \mathrm{The}$ results obtained by Stranick $^{28}$ for carbon steel in aerated and de-aerated molybdate solutions, are important, also, in this regard. The heavy pitting observed for the carbon steel in de-aerated solutions was explained in terms of the weakness of the steel as an oxidant.

The activity observed in the potential region -1200 to $-1400 \mathrm{mV}(\mathrm{SCE})$ on polarizing aluminium in the neutral molybdate solutions, Fig. 1A and B seem to be associated with a surface activation or modification process. The immediate current increase observed on addition of the molybdate solution to the electrode passivated 
at $-1350 \mathrm{mV}(\mathrm{SCE})$ (Fig. 1B), suggests the immediate onset of activation, but this is very quickly followed by repassivation. The rate of the current decay is somewhat slower during this second repassivation event, than that observed initially after polarization at $-2.0 \mathrm{~V}(\mathrm{SCE})$ in the chloride solution, evident from Fig. 1B. This may indicate that a mixed molybdenum and aluminium passive layer is formed as opposed to a simple hydrated aluminium oxide.

There may be some connection between this observation and that reported by Moshier and Davies, ${ }^{3}$ who observed increased film growth and an increase in the $\mathrm{MoO}_{2}$ signal on exposing aluminium to a molybdate solution at a $\mathrm{pH}$ value of 10.0 . In this present study too, alkaline conditions approaching $\mathrm{pH}$ values of 9.0 or 10.0 will exist at the metal oxide-solution interface because of alkalization ${ }^{13,14}$ at these low applied cathodic potentials. The mechanism by which the film thickens and $\mathrm{MoO}_{2}$ is formed is not clear, but an interesting correlation exists between these active potential values and the potential of $-1.214 \mathrm{~V}(\mathrm{SCE})$ calculated for the reduction of the $\mathrm{MoO}_{4}^{2-}$ species to $\mathrm{Mo}^{3+}\left(\mathrm{MoO}_{4}^{2-}+8 \mathrm{H}^{+}+3 \mathrm{e}^{-}=\mathrm{Mo}^{3+}+4 \mathrm{H}_{2} \mathrm{O} ; \mathrm{pH}=10\right.$, $\left.\left[\mathrm{Mo}^{3+}\right]=1 \times 10^{-6} \mathrm{~mol} \mathrm{dm}^{-3},\left[\mathrm{MoO}_{4}^{2-}\right]=0.1 \mathrm{~mol} \mathrm{dm}^{-3}\right)$. If this reaction could stimulate, or catalyse, the oxidation of aluminium (passive layer under these conditions would be highly hydrated and porous) then the increase in the film growth and the formation of $\mathrm{MoO}_{2}\left(\mathrm{Mo}^{3+}+4 \mathrm{H}_{2} \mathrm{O}=\mathrm{MoO}_{2}+4 \mathrm{H}^{+}+\mathrm{e}^{-}\right)$could be explained.

The relationship between the $\mathrm{pH}$ of the test solution and the passivity-promoting ability of the molybdate anion (Fig. 1A) is probably associated with the polymeric nature of molybdate species in acid solutions. ${ }^{21}$ For $\mathrm{pH}$ values between 6.0 and 14.0, the dominant species is the $\mathrm{MoO}_{4}^{2-}$ anion, for $\mathrm{pH}$ values between 6 and 4.5, $\mathrm{Mo}_{3} \mathrm{O}_{11}^{4-}$ becomes the preferred species, and with more acidic solutions, $\mathrm{pH}$ values ranging between 4.5 and 1.5, the polymeric anion $\mathrm{Mo}_{6} \mathrm{O}_{21}^{6-}$ becomes the dominant species. On the other hand, $\mathrm{Cr}_{2} \mathrm{O}_{7}^{2-}$ is the largest chromium species formed. This observation seems to point to a size effect where the larger polymeric molybdate species may not be accommodated at the flawed regions on the passive layer.

These $\mathrm{pH}$ results seem to be in conflict with the solubility arguments put forward by Smialowska ${ }^{11}$ in which the author explains the noble pitting potentials observed for aluminium-molybdenum systems in terms of the solubility of the oxidized species, $\mathrm{MoO}_{3}$. In this analysis, the author points to the fact that the solubility of the $\mathrm{MoO}_{3}$ oxide decreases with increasing acidity so that even at high anodic potentials where acidity increases the oxidized molybdenum species remains stable and superior pitting resistance is observed. Under the present experimental conditions, precipitation of the $\mathrm{MoO}_{3}$ species would be favoured. This may occur, but it does not appear to be the controlling factor in achieving passivation of the aluminium electrode.

The noticeable difference (Fig. 4) in the effects of molybdate and dichromate additions during metastable attack of aluminium in chloride solutions may again be associated with the oxidizing nature of the dichromate and molybdate species. Dichromate solutions, in the acidic conditions generated in developing pits, are powerful oxidizing agents and therefore, may facilitate the transformation of aluminium-hydroxy chloride complexes, e.g. $\mathrm{Al}(\mathrm{OH})_{2} \mathrm{Cl}$ to hydrated aluminium oxide, a process that has been described previously, for the extended immersion of aluminium in aqueous chloride solutions. ${ }^{29,30}$ Such a transformation agrees well with the immediate cessation of the current fluctuations (Fig. 4), indicative of the removal 
of chloride from the surface, and also, the radiotracer data of Tomyscanyi et al. ${ }^{31}$ in which a rapid decrease in the concentration of bonded chloride on addition of the dichromate salt was observed. This result highlights another important fact; once the chloride is displaced from the surface the subsequent adsorption of chloride, or reaction of chloride, at the surface is inhibited. The precipitation of a $\mathrm{CrOOH}$ film, as suggested by Smialowska, ${ }^{11}$ would indeed lead to the decay of the current fluctuations, but would not explain the sharp decrease in the concentration of bonded chloride observed by Tomyscanyi et al. ${ }^{31}$ In contrast, the oxidizing nature of the molybdate anion, at an applied potential of $-755 \mathrm{mV}(\mathrm{SCE})$, may not be sufficient to achieve these passivating reactions, or conditions.

The data presented in Fig. 5 may be explained in a similar manner. Continued passivation is observed in the presence of the dichromate species because of its ability, as an oxidizing agent, to heal developing pits. On the other hand, reduction of the $\mathrm{MoO}_{4}^{2-}$ anion may not be favoured, under such anodic conditions. These effects combined with the fact that insufficient incorporation of molybdenum is achieved prior to the application of the anodic potential leads to the development of active pits.

It may be concluded from these results, particularly those pertaining to the molybdate system, that chromium and molybdenum must be incorporated, effectively, into the developing film before passivation is observed. The significant displacement observed in the pitting potential of aluminium alloyed with molybdenum, compared with the effects observed here with molybdate solutions, show clearly, that the simple reduction of the molybdate anion at the surface is not sufficient to achieve passivation. Similar conditions operate with the dichromate anion, but because of its more powerful oxidizing nature, these effects are not apparent.

The exact mechanism by which the aluminium-chromium and aluminiummolybdenum surface alloys enhance the pitting resistance of aluminium is not clear, but the surface charge-adsorption theory, advanced by McCafferty et al. ${ }^{7-9}$ may be significant in light of the ability of dichromate species to displace chloride from the interface.

\section{REFERENCES}

1. J. Augustynski, in Passivity of Metals (eds R. P. Frankenthal and J. Kruger), p. 989. Electrochemical Society, Pennington, New Jersey (1978).

2. M. J. Abd Rabbo, J. A. Richardson and G. C. Wood, Corros. Sci. 15, 243 (1975).

3. W. C. Moshier, G. D. Davies and G. O. Cote, J. electrochem. Soc. 136, 356 (1989).

4. W. C. Moshier and G. D. Davies, Corrosion 46, 43 (1990).

5. B. A. Shaw, G. D. Davies, T. L. Fritz and K. A. Olver, J. electrochem. Soc. 137, 359 (1990).

6. A. Kh Bairamow, S. Zakipour and C. Laygraf, Corros. Sci. 25, 69 (1985).

7. P. M. Natishan and E. McCafferty, J. electrochem. Soc. 135, 321 (1988).

8. E. McCafferty, P. M. Natishan and G. K. Hubler, Corros. Sci. 30, 209 (1990).

9. P. M. Natishan, E. McCafferty and G. K. Hubler, Corros. Sci. 32, 721 (1991).

10. R. R. Wiggle, V. Hospadaruk and E. A. Styloglou, Mater. Perf. 20, 13 (1981).

11. Z. Szklarska-Smialowska, Proc. Symp. Critical Factors in Localised Corrosion, 9, 311 (1992).

12. L. Stockert and H. Boehni, Proc. 2nd Int. Conf. Localised Corrosion Orlando, CA (June 1987).

13. P. L. L. Cabot, J. A. Garrido, E. Perez and J. Virgili, Corros. Sci. 26, 357 (1987).

14. I. L. Rosenfeld, V. P. Persiantseva and V. E. Zorina, Proc. Metals (U.S.S.R.) 15, 69 (1979).

15. C. B. Breslin and W. M. Carroll, Corros. Sci. 34, 327 (1993). 
16. S. MATSUdA and H. H. UhLig, J. electrochem. Soc. 111, 156 (1964).

17. H. H. Uhlig and J. R. Gilman, Corrosion, 20, 289t (1964).

18. E. MCCAFFERTY, J. electrochem. Soc. 137, 3731 (1990).

19. N. Hackerman and R. A. Powers, J. phys. Chem. 57, 139 (1953).

20. E. S. Ivanov and N. G. Kluychnikov, Prot. Metals 5, 476 (1969).

21. M. Pourbaix, Atlas of Electrochemical data in Aqueous Solutions, NACE, CEBELCOR (1974).

22. E. McCafferty, M. K. Bernett and J. S. Murday, Corros. Sci. 28, 559 (1988).

23. J. K. Hawkins, H. S. Isacs, S. M. Heald, J. Tranquada, G. E. Thompson and G. C. Wood, Corros. Sci. 27, 391 (1987).

24. Kelil Videm, The Electrochemistry of Uniform Corrosion and Pitting of Aluminium, Kjeller Report, 62 (1974).

25. M. F. Abd Rabbo, J. A. Richardson, G. C. Wood and C. K. Jackson, Corros. Sci. 16, 677 (1976).

26. M. Koudelkova, J. Augustinski and H. Berthou, J. electrochem. Soc. 124, 1165 (1977).

27. H. Konna, S. Kobayashi, H. Takahashi and M. Nagayama, Corros. Sci. 22, 913 (1983).

28. M. A. Stranik, Corrosion, 40, 296 (1984).

29. R. T. Foley and H. T. NGuYen, J. electrochem. Soc. 129, 464 (1982).

30. W. M. Carroll and C. B. Breslin, Br. Corros. J. 26, 255 (1991).

31. L. Tomcsanyi, K. Varga, I. Bartik, G. Horanyi and E. Maleczki, Electrochim. Acta. 34, 855 (1989). 